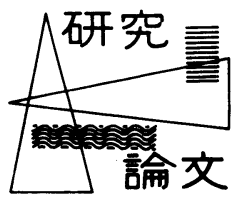

\title{
旋回火炎におけるすすの排出特性 についで
}

\section{西田修 身**}

Exhaust Characteristics of the Soots from Turbulent Swirling Flame

\author{
By Osami Nishida
}

In the general combustor, fuel and air are fed separately and combustion occurs primarily within a spacially limited zone. Turbulent mixing rates in such a system have important effects on the emission of pollutants such as unburned hydrocarbons and soot.

The main purpose of the present paper is to investigate on the control of the soot emission due to the different swirling intensities of combustion air flow. The blades of the swirl generator can change continuously from $0^{\circ}$ to $70^{\circ}\left(\theta_{b}\right.$ : swirl angle) in order to increase the tangential velocities. Characteristics of soot emission are measured in propane/air diffusion flames of two typically different combustor of parallel and enlarged types paying special attention to the roles of gas temperature on the behavior of soot formation and decomposition in the flames. Profiles of soot concentration together with gas temperature and entrainment rate of $\mathrm{O}_{2}$ are measured in all flames.

When the swirl angle $\left(\theta_{b}\right)$ is raised, both of the soot formation and decomposition rates increases. The larger angle of the $\theta_{b}$ results in the lower exhaustion of soot. However, in the enlarged combustor, finally exhausted soot concentration in the $\theta_{b}=70^{\circ}$ becomes much higher than that in the smaller angle $\theta_{\mathrm{b}}=60^{\circ}$ for the decay of soot decomposition in the down-stream.

\section{1. まえがき}

すす発生を抑制するためには，燃料と空気の混合を良 好にすることが考えられる.てれらの混合を促進する燃 焼法として旋回流火炎が一般に用いられている. この種, 火炎の流れの機構と混合特性を明白にするための研究が かなり進んでいる. しかしながら，すすの発生特性につ いての報告が非常に少なく，とくにガス燃料を用いて， 基礎的立場から研究された例は見当らない. 過去の報告 のすべては液体燃料を用いて行っている.Gills ${ }^{1)}$ はロー タリーバーナを用いて Cup の回転数を高くするほどす す量の低減勃果が大きいと報告している. Drake ら 蒸発量 9 ton/hr のボイラで空気流に旋回を加えて実験 をしており, バーナのレジスタベーンの角度が 40 度位 まではすす発生量が低減されるが, 40 度より大きくなる と再びすす発生量が増加するてとを報告している. また 広安ら ${ }^{3)}$ は定格燃焼器で非定常な噴蓩火炎で旋回器の回 転速度によるすす生成による影響を調べた結果, 燃焼初 期段階を除いては $5000 \mathrm{rpm}$ で最もすす生成量が少なく

\footnotetext{
*原稿受付 昭和 60 年 11 月 30 日

昭和 60 年秋季学術講演(昭和 60 年 10 月 23 日)

***正会員 神戸商船大学(神戸市東激区㳭江南町 5-1-1)
}

なると報告している．以上の測定例はすべて排気管出口 の代表場での測定報告である. 研究の目的が若干異なっ た報告として，D'Alessio ら ${ }^{4)}$ は弾性及び非弾性散乱光 の強度を測定する方法で, \# 2 燃料油で空気流に旋回を 加えた影響を，すすによる散乱と液滴からの散乱を区別 しながら測定しており，高いスワールの火炎ほど，滴及 びすすの散乱光強度が小さいと報告している.

本報告ではプロパン・空気系の火炎でノズル及び炉の 形態をかえて，空気に旋回をくわえ，すすの発生状況を 測定した.さらに空気温度を加熱したり，窒素ガスを燃 料中に添加した場合についても測定し，種々検討を試み た.

\section{2. 実験装置及び方法}

\section{1 燃焼器旋回燃焼器の詳細を図 1 亿示す.} 燃焼用空気はブロワーにより 2 方向から強制通風により 空気予熱室へ供給される. 加熱法は 5 本のシリコニット $(14 \mathrm{~mm}$ 径, 長さ $900 \mathrm{~mm}$, 出力 $3.16 \mathrm{~kW})$ で形成されて いる. 加熱された空気は縮流部, 補助空気予熱室 (マイ クロヒータ, O. D $\phi 1.6 \mathrm{~mm}$, 長さ $5000 \mathrm{~mm}, R_{0}=11.0$ $\Omega / \mathrm{m}$ )を通過し, 仕切板を通り, 周囲より半径方向に取 り付けた 8 枚の対称翼からなる旋回発生用案内羽根 (以 


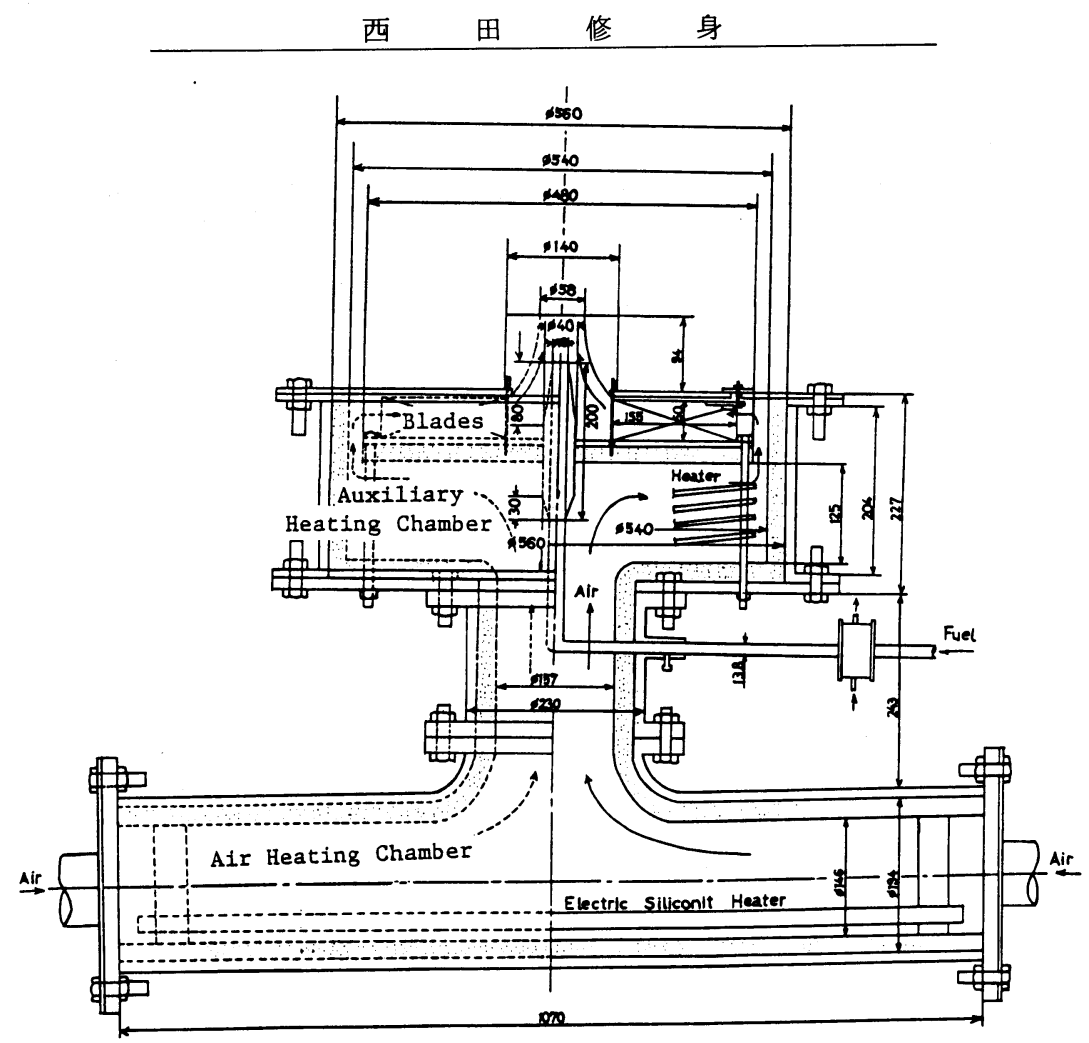

図 1 旋回燃焼器

後, 旋回羽根之呼ぶ）を通過し，旋回を与えられた空気 流は縮流部を通ってパイレックスガラス製の燃焼炖へと 導汃れる. 旋回強度は 8 枚の旋回羽根の子午面加らの傾 き角 $\left(\theta_{\mathrm{b}}\right.$ : 旋回羽根角度) によって調節することが出来る。 なお， $\theta_{\mathrm{b}}$ は 0 度から 70 度までの範囲で連続的に変える ことが可能である. また, 燃焼用空気温度の検出は火炎 からのふく射の影響を避けるため燃料ノズル先端から $60 \mathrm{~mm}$ 上流の位置で $\mathrm{CA}$ 熱電対により行った.

燃焼炉及び燃料ノズルの詳細は図 2 亿示す。燃焼炉 の形態には縮流部を経た空気が平行流として炉内径 58 $\mathrm{mm}$, 高さ $700 \mathrm{~mm}$ の炉へ導かれる (I) 型の平行炉と空 気流が内径 $114 \mathrm{~mm}$, 高さ $640 \mathrm{~mm}$ の炉内へと急に断面 積の大きい炉内に流れ込む (II) 型の拡大炉の 2 種類があ る. 燃焼ノズルの先端は縮流部出口から高さ $128 \mathrm{~mm}$ の 位置にあり, 内径 $6.0 \mathrm{~mm}$, 外径 $9.0 \mathrm{~mm}$ 及び内径 $4.0 \mathrm{~mm}$, 外径 $6.0 \mathrm{~mm}$ の 2 種類を使用した. 以上のように，2 種 類の燃焼炬と燃料ノズルを組み合せることによって, 基 本的に 4 種類の火炎を形成することが出 来る. その分類を表 1 亿示す. 表中には 燃料であるプロパンガスのノズル管内の 平均速度とレイノルズ数を併記した.な お，実験には室温 $25^{\circ} \mathrm{C}$ ，大気圧の下で $\mathrm{C}_{3} \mathrm{H}_{8}$ 流量 $0.6 \mathrm{~L}_{\mathrm{N}} / \mathrm{min}$, 空気流量 240 $L_{\mathrm{N}} / \min$ により形成した火炎を標準火炎 とした。ただし， $L_{\mathrm{N}} / \mathrm{min}$ は標準状態で

Journal of the M.E.S.J., Vol.21, No.6
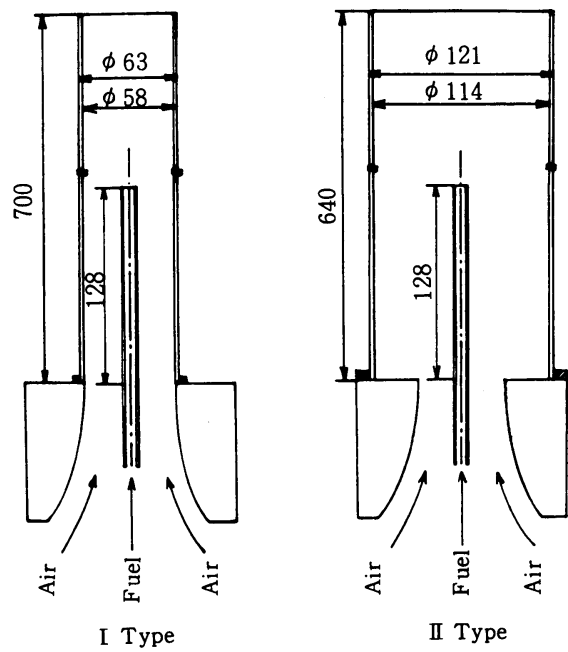

図2 燃焼炉及び燃料ノズル

表 1 実験条件

( $\left.25 \mathrm{C}, 1 \mathrm{~atm}, \mathrm{C}_{3} \mathrm{H}_{8}=0.6 L_{\mathrm{N}} / \mathrm{min}, \operatorname{Air}=240 L_{\mathrm{N}} / \mathrm{min}\right)$

\begin{tabular}{|c|c|c|c|c|}
\hline $\begin{array}{l}\text { Flame } \\
\text { Type }\end{array}$ & $\begin{array}{l}\text { Fuel Nozzle } \\
\text { Inner, Outer } \\
\text { Diameter }(\mathrm{mm})\end{array}$ & $\begin{array}{c}\text { Combustion Furnes } \\
\text { Inner Diameter } \\
(\mathrm{mm})\end{array}$ & $\begin{array}{c}\text { Fuel } \\
\text { Velocity } \\
U_{0}(\mathrm{~m} / \mathrm{sec})\end{array}$ & $\begin{array}{c}\text { Reynolds' } \\
\text { Number } \\
R e\end{array}$ \\
\hline (A) & $6.0,9.0$ & 58 & 0.35 & 465 \\
\hline (B) & $6.0,9.0$ & 114 & 0.35 & 465 \\
\hline (C) & $4.0,6.0$ & 58 & 0.80 & 710 \\
\hline (D) & $4.0,6.0$ & 114 & 0.80 & 710 \\
\hline
\end{tabular}




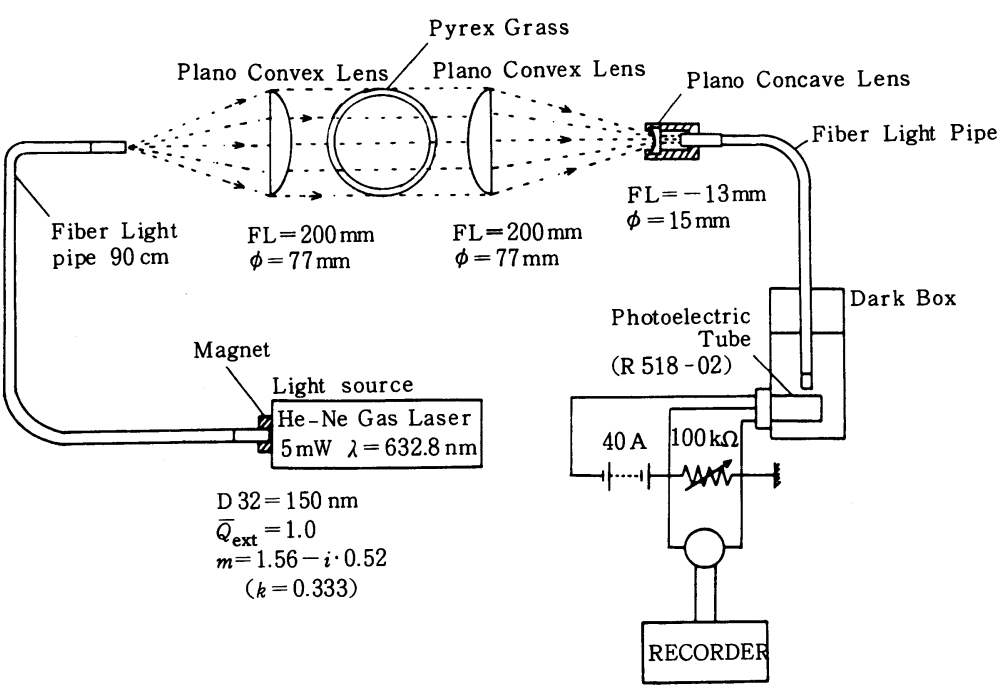

困 3 光学系測定装置

の体積流量 $(L / \mathrm{min})$ を示す.

2.2 測定法燃焼炉出口断面部でのすすの数密 度及び体積分率の測定に使用した光学測定装置の概略を 図 3 に示す. 光源にはレーザ $(\mathrm{He}-\mathrm{Ne}$, 波長 $632.8 \mathrm{~nm}$, 出力 $5 \mathrm{~mW}$ )を用い, レーザ本体の前に光ファイバース コープを固定した. 光線は光ファイバースコープ先端か ら約 $60^{\circ}$ の広がり角度をあって平凸レンズを経た後, 平 行光線となり測定部に入射する. 測定部からの透過光は 平凸レンズにより集光され，さらに平凹レンズを経た後， 再び平行光線となり光ファイバースコープにより暗箱内 の光電管により受光され，電気信号に変換された後，ミ リボルト計により読みとった. 測定位置は平行炉におい てはノズル先端からの高さ $L_{\mathrm{c}}=600 \mathrm{~mm}$, 拡大炉におい ては $L_{\mathrm{c}}=550 \mathrm{~mm}$ に設置した. 以上の方法により読み取 った入射光及び透過光強度により, すすの数密度及び体 積分率はすす粒子径を電子顕微鏡撮影写真から投影面積 の測定により得た平均凝集体の体面積平均粒子径 $\left(\bar{D}_{32 \mathrm{~S}}\right)$ $150 \mathrm{~nm}$ に対して, 平均減衰係数 $\left(\bar{Q}_{\text {ext }}\right)$ を $1.0(m=1.56$ $-i \cdot 0.52, m$ : 複素屈折率, $i$ : 虚数の単位)として計 算した. すす重量濃度の測定法は従来から行ってきた等

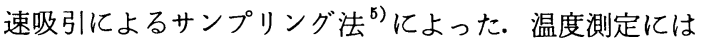
$\mathrm{Pt}-\mathrm{Pt} \cdot \mathrm{Rh}(13 \%) ， \phi 0.1 \mathrm{~mm}$ 熱電対で計り，ふく射に よる補正は行っていない. また, 酸素濃度はガスサンプ リングプローブにより捕集し, ジルコニア式酸素濃度計 （富士産業株式会社製）で，連続的に測定した.

\section{3. 実験結果及び考察}

3.1 火炎形状表 1 のような 4 種類の火炎につ いて, 旋回強度を変えることによって火炎形状を観察し た. 全般的に平行炉による (A) と (C) 型火炎, 拡大炉に よる (B) と (D) 型火炎はよく類似している。(A) と (C) 型火炎は $\theta_{\mathrm{b}}=0^{\circ}$ では火炎全長は約 480 $500 \mathrm{~mm}$ で燃料
ノズル先端から約 $200 \mathrm{~mm}$ の高 さ付近までの上流域では乱れが なく，下流域で若干の乱れが生 ずる程度のローソク炎が伸長し た棒状火炎を形成する. 旋回羽 根角度を増していくと，火炎は ねじれ，下流域での乱れが激し くなり，火炎長さは短く， / ズル近傍で半径方向に広がりを あつ火炎へ之遷移して行く.さ らに旋回羽根角度を増す之，火 炎長さは短くなり半径方向への 広がりあ大きくなり，ノズル近 傍の上流域であ乱れを生じ，全 体的に凹凸の激しい火炎となる 旋回羽根角度 $70^{\circ}$ において, 約 $250 \mathrm{~mm}$ の火炎長さになる. 拡 大炉である (B) と (D) 型火炎で は平行炉に形成される火炎にくらべ全体的に火炎長さは 短く, 半径方向に大きく広がった乱れの大きな火炎とな る. 旋回を与えない場合 $\left(\theta_{\mathrm{b}}=0^{\circ}\right)$ は火炎長さは約 240 $\mathrm{mm}$ 程度で, ノズルから約 $30 \mathrm{~mm}$ までは乱れは小さく, 少しゆらぎを生ずる程度であるが，下流へ行くにしたが って乱れが大きくなり，半径方向に大きく広がりを有す る逆円すい状火炎となる. 旋回羽根角度を増していくと, 逆円すい状火炎はノズル近傍でさえ凹凸の激しい乱れを 形成し, 火炎長さの短いボール状火炎へと遷移していく. さらに旋回羽根角度を $70^{\circ}$ と大きくすると, ボール状火炎 の下流端が部分的な浮き上がりを生じる様になる. 以上 の 4 種類の火炎 [(A), (B), (C), (D)]における旋回羽根 角度と火炎長さの関係を図 4 亿示す. 火炎長さは同一条 件で数枚直接撮影 (シャッター・スピード：1/500 で撮影) した写真から決定した. 平行炉に形成される(A)，(C)型

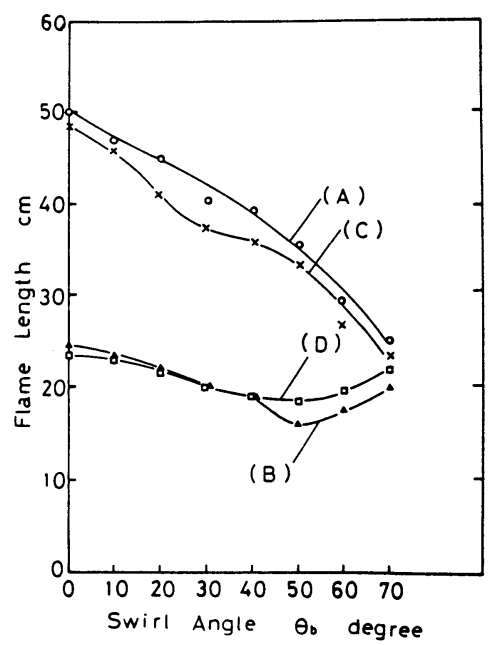

困 4 火炎長さ 
火炎では，旋回羽根角度を大きくするにしたがい火炎長 さは単調に短くなり, $\theta_{\mathrm{b}}=70^{\circ}$ の場合は $\theta_{\mathrm{b}}=0^{\circ}$ にくらべ 約 $1 / 2$ の長さになる. また，拡大炉に形成される(B), (D) 型火炎では旋回羽根角度の変化に対する火炎長さの 変化は平行炉ほど大きくなく, 全体的に変化率は小さい.

3.2 旋回強度に対するすす排出特性平行炉 による (A)，(C) 型火炎における数密度 $\left(N_{\mathrm{S}}\right.$ : Particles

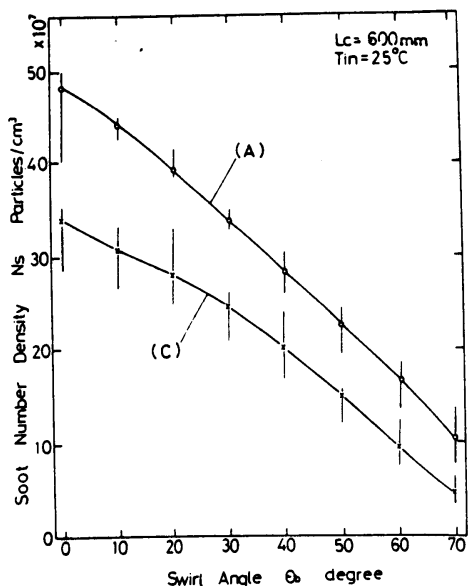

(a) 数密度分布

図 5 平行炉での (A)，(C) 型火炎からのすす排出量 $\left(L_{\mathrm{c}}=600 \mathrm{~mm}\right.$ 位置 $)$ $\left./ \mathrm{cm}^{3}\right)$ 及び体積分率 $\left(V_{\mathrm{S}}: \mathrm{cm}^{3} / \mathrm{cm}^{3}\right)$ を図 $5(\mathrm{a})$,(b) に 示す. (A) 型火炎では, 数密度及び体積分率ともに旋回羽 根角度 $0^{\circ}$ に扔いて $N_{\mathrm{S}} \doteqdot 50 \times 10^{7} \mathrm{Particles} / \mathrm{cm}^{3} ， \quad V_{\mathrm{S}}$ $\doteqdot 2.6 \times 10^{-7} \mathrm{~cm}^{3} / \mathrm{cm}^{3}$ となり, 羽根角度の增加に伴い 単調に減少し, 旋回羽根角度 $70^{\circ}$ において, $N_{\mathrm{S}} \doteqdot 10 \times$ $10^{7}$ Particles $/ \mathrm{cm}^{3}, \quad V_{\mathrm{S}} \doteqdot 0.6 \times 10^{-7} \mathrm{~cm}^{3} / \mathrm{cm}^{3}$ を示す. (C) 型火炎は (A) 型火炎と同じような傾向を示すが, 全

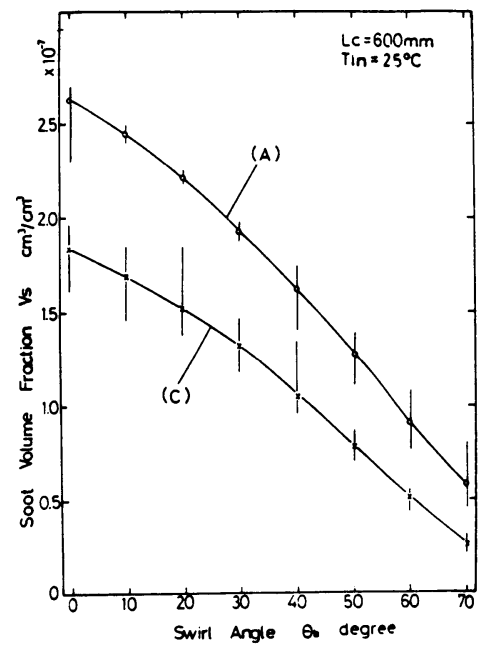

（b）体積分率分布

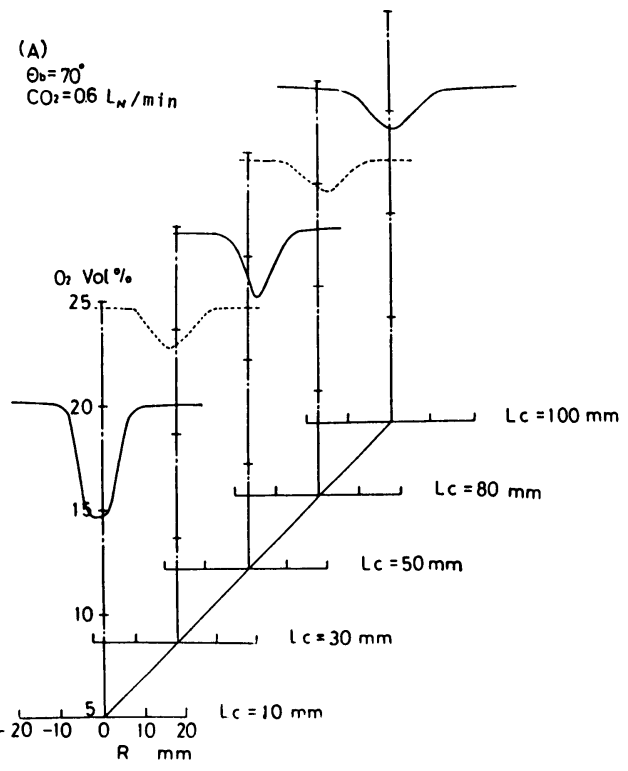

（a）（A）型噴流

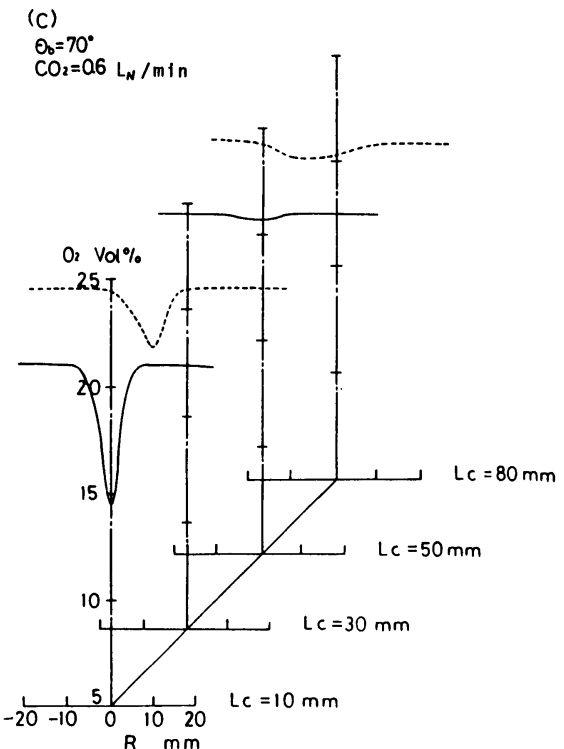

（b）（C）型噴流

図 6 平行炉での $(\mathrm{A})$ 及び $(\mathrm{C})$ 型噴流の酸素濃度分布 (旋回羽根角度 $\theta_{\mathrm{b}}=70^{\circ}$ ) 

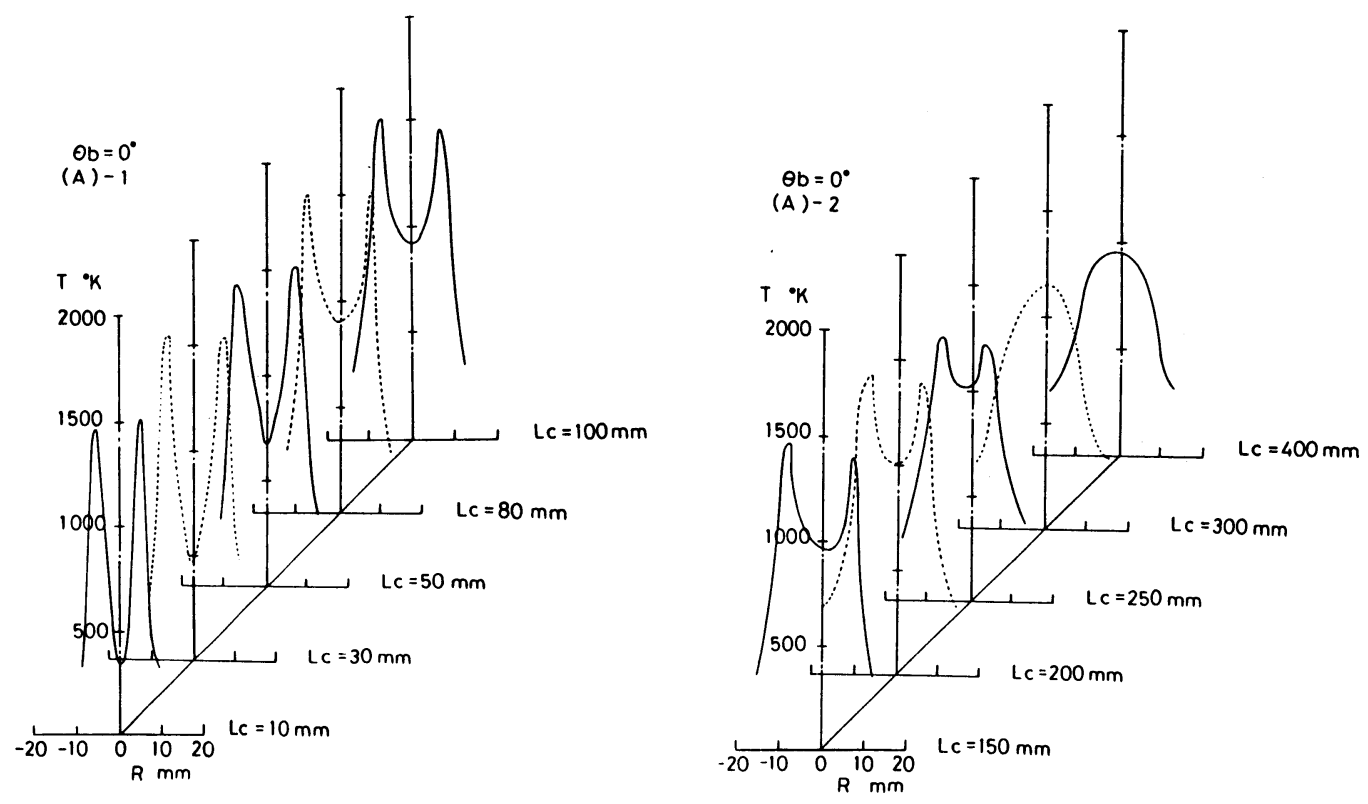

(a) 旋回羽根角度 $\theta_{\mathrm{b}}=0^{\circ}$
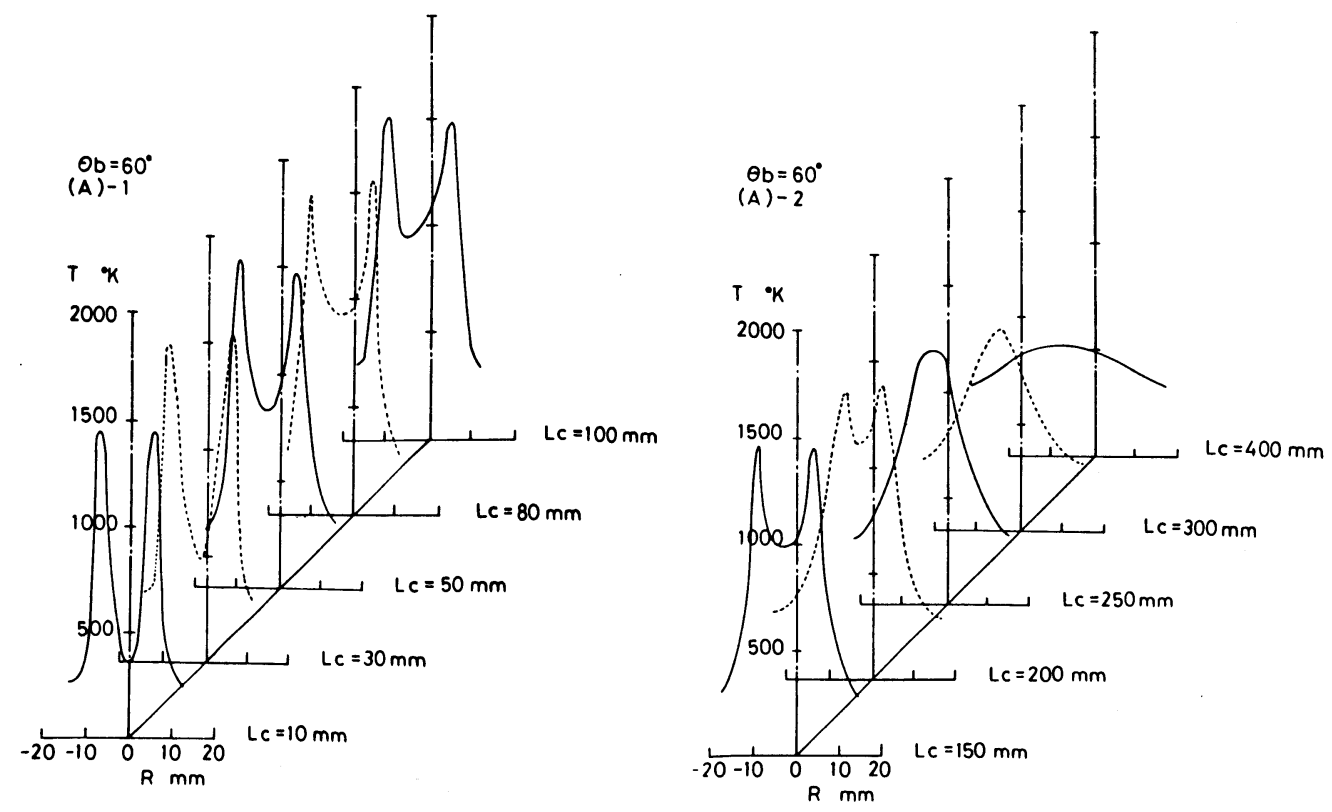

（b）挍回羽根角度 $\theta_{\mathrm{b}}=60^{\circ}$

図 7 (A) 型火炎の燃焼ガス温度分布 $\left(L_{\mathrm{c}}\right.$ : 軸方向, $R$ : 半径方向 $)$ 
体の排出レベルは低くなる．乙れは燃料噴出速度が大き いため空気の誘入は著しく火炎の乱れは若干激しくなり， 周囲空気との混合が活発なため，すすの排出量は減少し 数密度, 体積分率ともに全体的に減少する. この検証と して，プロパンガスの換りに，同量の炭酸ガスを噴出し た場合, 周囲流である空気の誘入量の差異を酸素濃度分 布で示したのが図 6 (a)，（b)である. なお，旋回角度 は70である. 図より，(C) 型噴流ではノズル先端から $50 \mathrm{~mm}$ 付近で, 酸素濃度はほとんどフラットな分布とな り，ノズル噴出口径が小さくなるほど，一次及び二次流 の混合が迅速になるといえる. 平行炉に形成される旋回 火炎で燃料流速に関係なく, 旋回羽根角度の増加に伴い 燃焼炉出口でのすす排出量は単調に減少する原因は旋回 空気流の半径方向及び周方向の運動量が大きくなれば燃 料噴流中心の燃料過濃な領域への酸素混入率が増大し, 反応の進行が促進され未燃分の排出が抑制されるためと 考えられる. 図 7 (a), (b), 図 8 (a), (b) 飞(A) 型火炎 の旋回羽根角度 $0^{\circ}$ と $60^{\circ}$ の場合についての火炎後流域の 温度履歴及び火炎軸方向のすす重量濃度と温度分布を示 した. 図 7 (a)より, $\theta_{\mathrm{b}}=0^{\circ}$ では $L_{\mathrm{c}}=250 \mathrm{~mm}$ 付近まで は鞍型分布を呈し，十分に火炎中心部まで反応は進んで いない,さらに図8（a）においても，温度ピーク位置は $300 \mathrm{~mm}$ 付近であり $250 \mathrm{~mm}$ 近傍で最もすすが生成され ている. しかしながら， $\theta_{\mathrm{b}}=60^{\circ}$ では図7 (b)において，

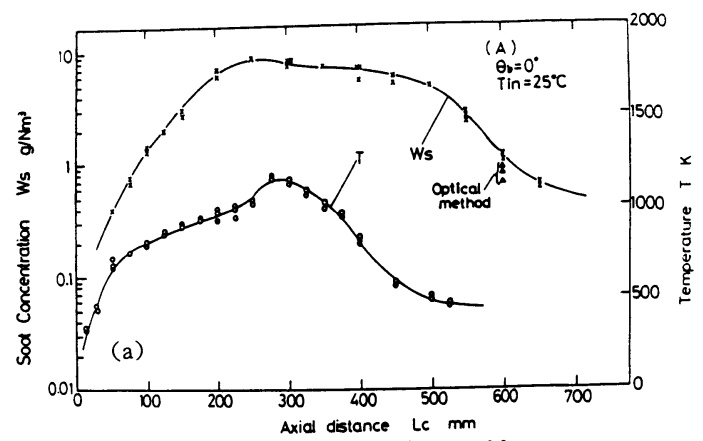

（a）旋回羽根角度 $\theta_{\mathrm{b}}=0^{\circ}$

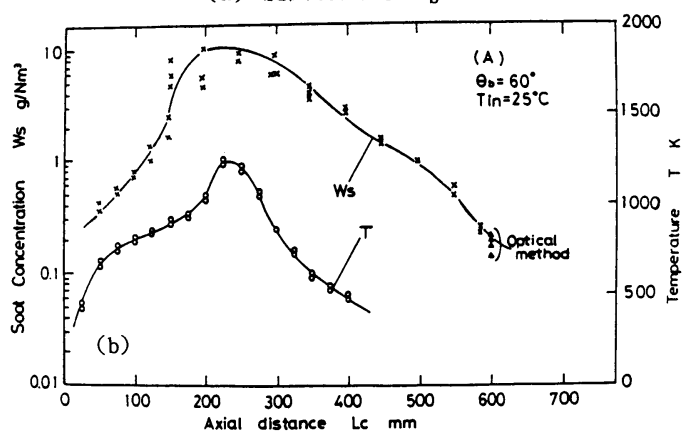

（b）旋回羽根角度 $\theta_{\mathrm{b}}=60^{\circ}$

図 8 (A) 型火炎の火炎軸方向のすす重量濃度と 温度分布
$L_{\mathrm{c}}=250 \mathrm{~mm}$ の付近で，すでに火炎中心部で反応が進行 しており，つり鐘状の分布を示している．乙のととは図 8 (b)においてあ同様であり, 反応が全体に上流側にシ フトしている. ゆえに旋回を加えることによって，燃料 之空気の混合が促進され，反応が速くなる．すすの生成 速度も同様に速くなるが分解に要する時間が十分存在す るため, 最終的な排出量は著しく低減される。

図 9 亿拡大炬による(B) と (D) 型火炎におけるすすの 体積分率を示す. 両火炎とあ平行炉による (A) と (C) 型 火炎の結果にくらべると，すすの排出量は著しく減少し， 数密度及び体皘分率は $1 / 10$ のオーダとなる.（B）型火 炎では数密度及び体積分率は旋回羽根角度 $0^{\circ}$ において最 高値 $\left(N_{\mathrm{S}} \doteqdot 35 \times 10^{6}\right.$ Particles $/ \mathrm{cm}^{3}, \quad V_{\mathrm{S}} \doteqdot 2.2 \times 10^{-8}$ $\mathrm{cm}^{3} / \mathrm{cm}^{3}$ ) となり, 羽根角度の増加に伴い単調に減少す るが，旋回羽根角度 $60^{\circ}$ において最低值 $\left(N_{\mathrm{S}} \div 18 \times 10^{6}\right.$ Particles $/ \mathrm{cm}^{3}, V_{\mathrm{S}} \doteqdot 1.0 \times 10^{-8} \mathrm{~cm}^{3} / \mathrm{cm}^{3}$ )を示した後, 再び旋回羽根角度 $70^{\circ}$ に打いて增加する. (D) 型火炎は （B）型火炎之同じ傾向を示すが，燃料噴出速度の増大に 伴う乱れの形成により周囲空気との混合が活発で, 排出 されるすすの数密度及び体皘分率は全体的に (B) 型火炎 にくらべ減少する．図10(a), (b)及び図 11 (a), (b), (c) に(B) 型火炎についての旋回羽根角度に対する温度履歴 と火炎軸方向のすす重量濃度と温度分布を示した。図 10 より, $\theta_{\mathrm{b}}=0^{\circ}$ ではノズル近傍の火炎中心部の反応が十分 進行していないが, $\theta_{\mathrm{b}}=60^{\circ}$ ではノズル先端部から, 燃 料と空気の混合が促進され，反応が進行している. 図11 から，旋回強度を増すと温度ピーク值の位置が上流側へ 移行し，すす生成速度が速くなる． $\theta_{\mathrm{b}}=60^{\circ}$ ではすすの 分解屯進行し, 最終的には低濃度となる。 しかし， $\theta_{\mathrm{b}}$ $=70^{\circ}$ においては空気の横方向流量が増すため, $L_{\mathrm{c}}=80$ $\mathrm{mm}$ 以降での温度レベルが $\theta_{\mathrm{b}}=60^{\circ}$ の場合 [(b) 図〕より

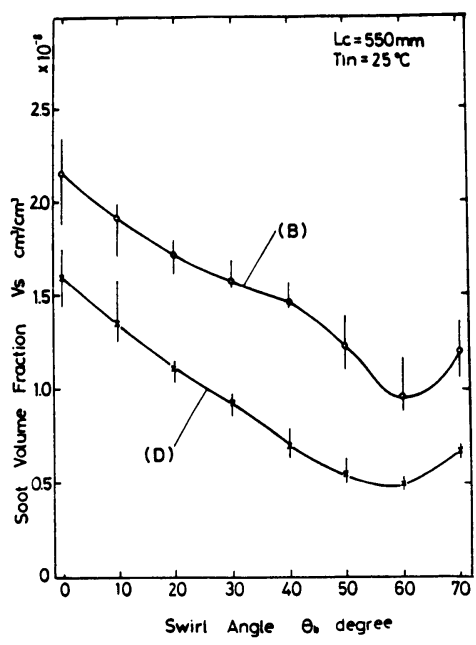

図 9 拡大炉での (B)，(D) 型火炎からの すす排出量 $\left(L_{\mathrm{c}}=550 \mathrm{~mm}\right)$ 


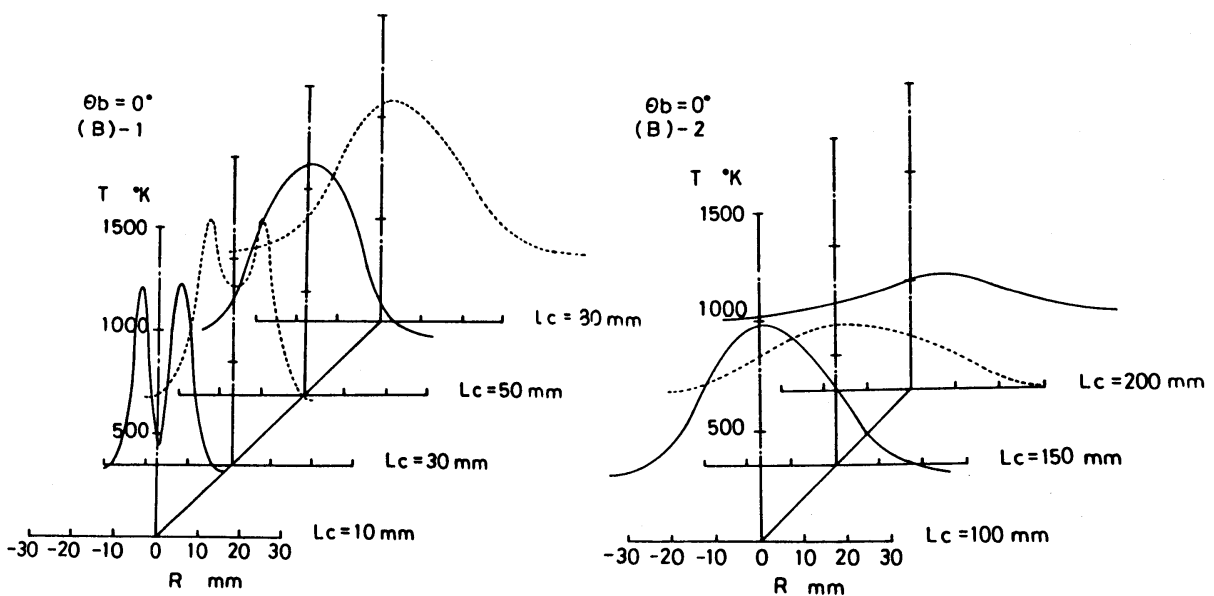

（a）旋回羽根角度 $\theta_{\mathrm{b}}=0^{\circ}$

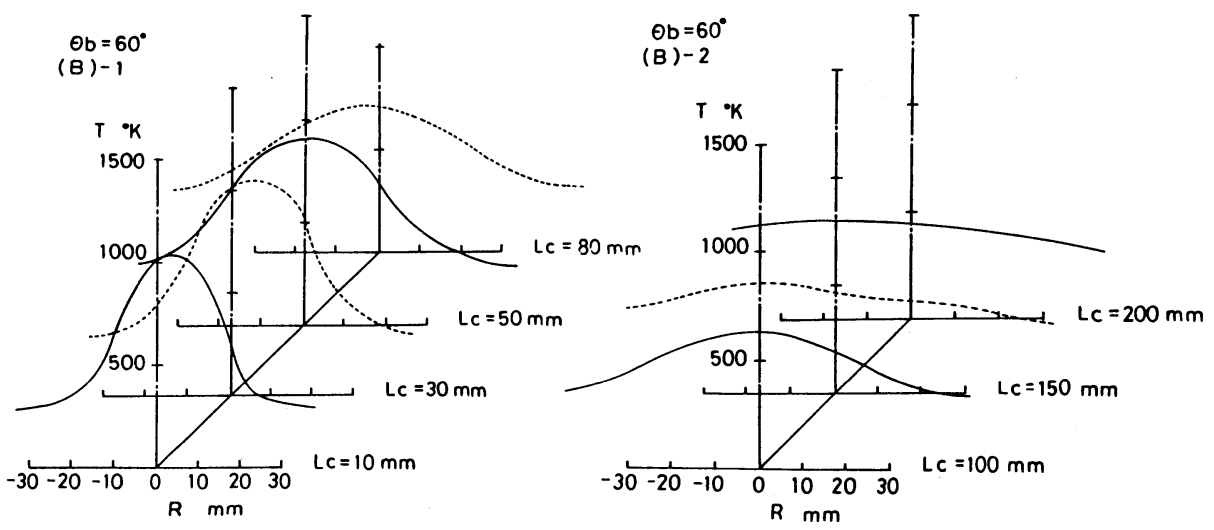

（b）旋回羽根角度 $\theta_{\mathrm{b}}=60^{\circ}$

図 10 (B) 型火炎の燃焼ガス温度分布

低くなることより，すすの分解が不十分であり，最終的 なすす排出量は增加する.

\section{3 燃焼状態をかえた場合のすす排出特性}

燃料流量 $\left(0.6 L_{\mathrm{N}} / \mathrm{min}\right)$ を一定とし, 燃料中に窒素ガ スを添加した場合のすす排出特性についてのべる. 図 12 には拡大炉による(B) と(D)型火炎に窒素ガスを 0.1 $L_{\mathrm{N}} / \mathrm{min}$ 添加した場合のすす体積分率 $\left(V_{\mathrm{S}}\right)$ を示す。 そ の場合の燃料ノズル噴出時の平均流速 $\left(U_{0}\right)$ 及びレイノル ズ数 $(R e)$ は (B) 型火炎では $U_{0}=0.41 \mathrm{~m} / \mathrm{s}, R e=500$, (D) 型火炎では $U_{0}=0.93 \mathrm{~m} / \mathrm{s}, \quad R e=750$ となる.なお, 乙の場合の両火炎の火炎形状は窒素ガス無添加の場合に くらべて，火炎の乱れが若干増し輝度が低下する．両火 炎ともすすの体積分率は窒素ガス無添加時 (図中破線で 示す）にくらべて，旋回羽根角度に対して同じような傾 向で減少するが, 窒素ガスの添加によって著しく減少す る. 窒素ガス添加によりすすの排出量が低減する原因と して燃料ノズル噴出時の速度の增加に伴い火炎の乱れが 增し火炎面積も増大して空気混入が促進されることや燃
料分圧の低下が考えられる. しかし窒素ガスを添加して 屯両火炎において, 最適旋回羽根角度 $\left(\theta_{\mathrm{b}}=60^{\circ}\right)$ 以上で の羽根角度の增加に伴うすす排出量の単調減少は見られ ない。

燃焼用空気温度 $\left(T_{\text {in }}\right)$ を上昇させた場合の火炎形状 $\left(T_{\text {in }}\right.$ $\left.=150^{\circ} \mathrm{C}\right)$ は標準火炎 $\left(T_{\text {in }}=25^{\circ} \mathrm{C}\right)$ にくらべて乱れは激し くなり, 輝度は増し火炎全体が振動し火炎長さは若干短 くなる. 図 13 亿拡大炉による(B) と (D) 型火炎の燃焼 用空気温度を上昇させた場合のすすの体積分率を示す. 両火炎とも燃焼用空気温度を上昇させるととにより，す す体積分率は著しく減少するが，旋回羽根角度による依 存性は標準火炎(図中に破線で示す)の場合と一致してお り, 分布形状に差異はなく旋回羽根角度 $60^{\circ}$ にて最適值 を有する．空気温度の上昇にとあなうすす排出の低減効 果は, 火炎温度の上昇により, すすの生成速度が増加す るが，それ以上に分解過程が進むため, 最終的なすす排 出量は低減される ${ }^{6)}$. 


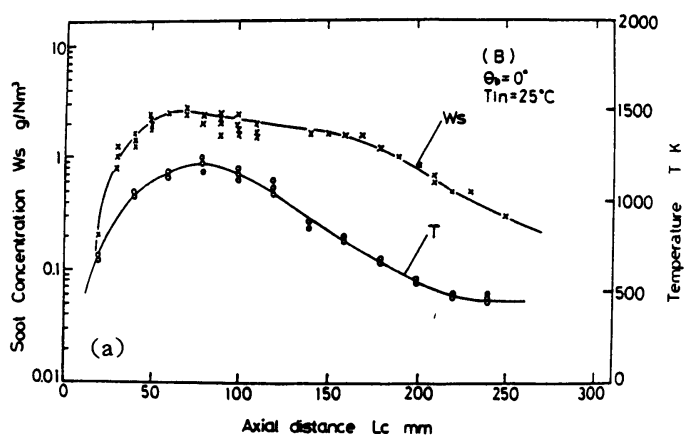

（a）旋回羽根角度 $\theta_{\mathrm{b}}=0^{\circ}$

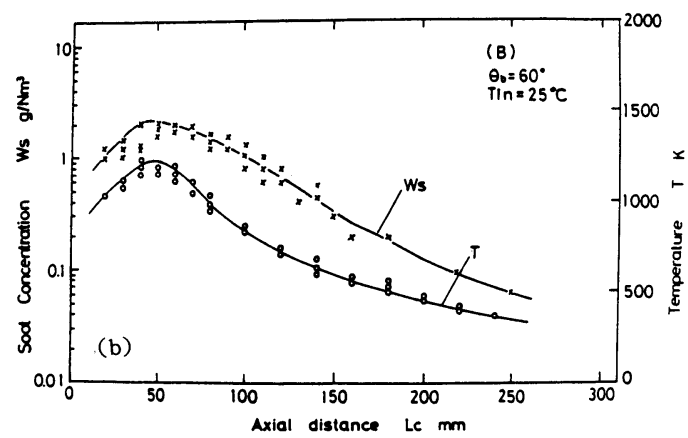

（b）旋回羽根角度 $\theta_{\mathrm{b}}=60^{\circ}$

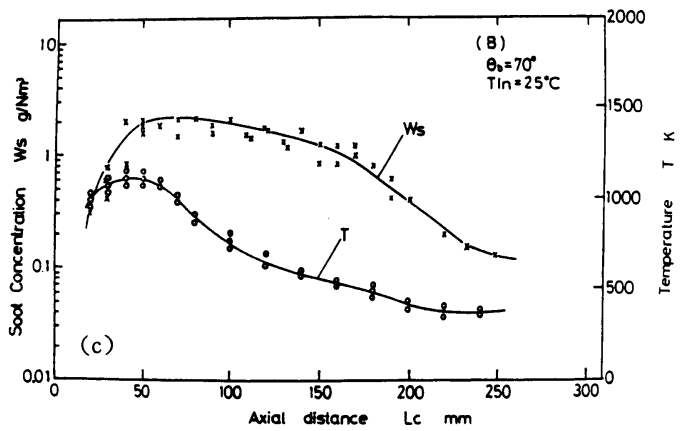

（c）旋回羽根角度 $\theta_{\mathrm{b}}=70^{\circ}$

図 11 （B) 型火炎の火炎軸方向のすす重量濃度と 温度分布

\section{4. まとめ}

プロパン・空気系拡散火炎を用いて, 燃料炉及び燃料 ノズルを種々かえて, 周囲空気流に旋回を与えた場合, 火炎形状及びすす排出特性について，測定した結果よ り，つぎのようなことが明らかになった。

（1）旋回羽根角度を増していくと，火炎長さは短くな り, 半径方向に広がりをもつ乱れの大きい火炎へと遷移 していく, 平行炉型火炎では, とくにこの傾向が強い. しかしながら，本実験で使用した拡大炉による旋回羽根 角度の変化に対する火炎長さはほとんど変化がなかった.

（2）空気流に旋回を加えると, 反応は全般に上流側に

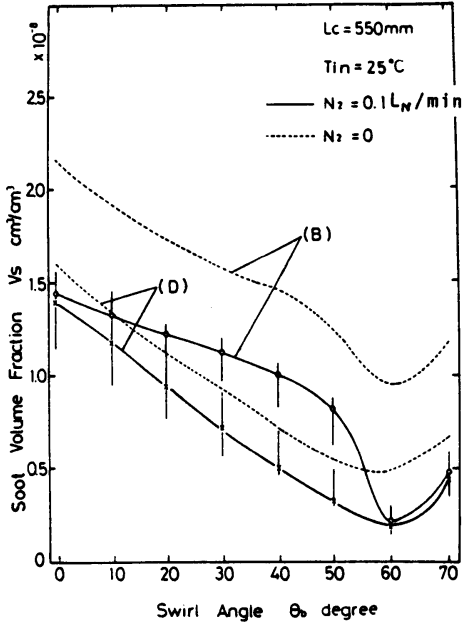

図 12 燃料中に窒素ガス添加の影響

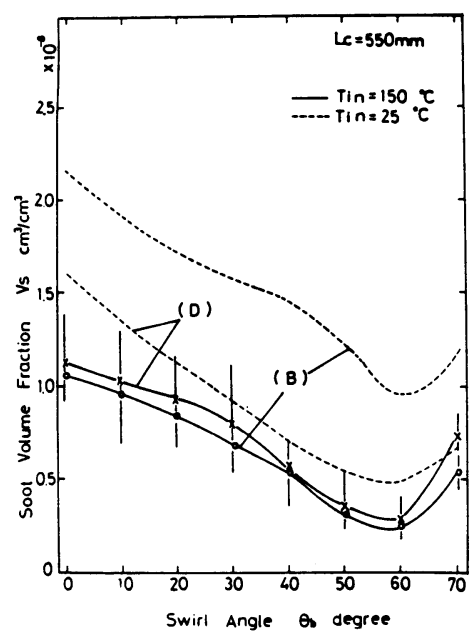

図 13 燃焼用空気温度を上昇させた場合 の影響

移行し，すすの生成は迅速であるのに対して，すすの分 解が十分な時間を経て進行するため，最終的なすす排出 量は低減される.

（3）平行炉に形成される火炎では旋回羽根角度の増加 に伴いすす排出量は単調に減少する. しかし，拡大炉に て形成される火炎では，すす排出量に対する最適旋回羽 根角度 $\left(\theta_{b}=60^{\circ}\right)$ が存在し，それ以上の旋回羽根角度で はすすの排出量が増加する. これは, 拡大炉では半径方 向への空気流量が増し, 反応が凍結し, すすの分解が抑 制されるためである.

（4）燃料ノズル内径が小さくなると燃料噴出速度が大 きくなるので, 火炎の乱れは若干激しくなり, 周囲空気 
との混合が活発化して，すす排出量は減少する.

（5）燃料中へ窒素ガスを添加した場合のすす排出量の 低減効果は燃料の噴出速度を高めた場合の (4)の結果と 同様な現象が見受けられるが，窒素ガス添加による燃料 分圧の低下による反応速度の抑制が主原因である.

（6）燃焼用空気温度を上昇させると，火炎全体の温度 が上がる. とくに火炎下流域ですすの分解作用が効果的 であり，最終的な排出量は低減される.

おわりに，本研究の遂行にあたって，文部省科学研究 (昭 $58,59,60$ 年度特定研究 I, 燃焼現象のレーザ計測 とモデリング)費及び日本機械学会 (RC 61, ディーゼル 機関における粒状排出物の低減と低質燃料の燃焼に関す る研究分科会：昭 $57,58,59$ 年)の補助を受けた. 深く 感謝致します.

\section{文献}

1) Gills, B. G., Journal of the Institute of Fuel (1973-2), 71.

2) Drake, P. F. and Hubbard, E. H., Journal of the Institute of Fuel, XXXIX-302 (1966-3), 98.

3) 中西·新井·広安, 日本機械学会論文集, 49-437 (昭 58), 255.

4) Beretta, F., Cavaliere, A. and D'Alessio, A., Combustion Science and Technology, Vol. 27 (1982), 113.

5) Nishida, O. and Mukohara, S., Combustion and Flame, 47-3 (1982), 269.

6) 文献 5) に同じ.

\section{〔質 疑 応 答〕}

質問者 東京商船大学機関学科 岡田 博

〔質問〕測定法について，次の質問をします。

1. 透過法を用いて, 粒子径 (数)を求めるときは, 光 の波長に対して粒子径が十分に小さい必要がありますが, ての点を考慮してあるか。

2. 図 3 の光学系に沶いて，すす粒子による入射光の 散乱を検知しないように考慮されているか. 考慮されて いるのであれば説明して下さい.

3. 火炎形状は凹凸の激しいものとなっているが，そ れらから図 4 の関係を得るには，どのような整理方法を 用いたのか.

〔回答〕（1）G. Mie の光散乱理論より, 複素届折率 $m=1.56-i \cdot 0.52$ を用い, 粒度分布を考慮して, 平均減 衰係数 $\bar{Q}_{\mathrm{ext}}$ に対する体面積平均粒子径 $\left(\bar{D}_{32}\right)$ を算出した
結果, $\bar{D}_{32}=400 \mathrm{~nm}$ 程度までは $\bar{Q}_{\text {ext }}$ が単調に增加して いるため, 測定が十分可能である.

（2）光学系より散乱角度 $(\theta)$ を最大限に見積もっても 5 度以内となる. また, ラテックス球を蒸留水中に浮遊 させた試料で散乱光の有無を調べたが, 受光されていな いことが検証済である.

（3）火炎はシャッター・スピード $1 / 500$ で撮影した写 真より. 図 4 はそれらの写真より, 火炎先端の長さを求 め, 整理したものである. ゆえに, 火炎面の乱れの強さ (凹凸状態)は関係ありません，

質問者 広島大学工学部 新井雅隆

〔質問〕（1）図 5 では数密度分布と体積分率分布を示 していますが，すす粒子の平均粒径を $150 \mathrm{~nm}$ として計 算した結果であるため, どちらか一方の分布で十分では ないでしょうか。

（2）火炎軸方向のすす重量濃度と温度分布を比較した 図(例えば図 8)を調べると火炎後半部分で温度が $500 \mathrm{~K}$ 以下に低下した後でもすす重量濃度が減少している. 500 $\mathrm{K}\left(227^{\circ} \mathrm{C}\right)$ 程度の温度ではすすの酸化による分解反応は ほとんどおきないと考えられるから，火炎後半でのすす 濃度の減少過程には, 生成したすすの半径方向への拡散 による減少効果が相当大きいと思われます．とのように 考えますと，すすの分解による減少効果をての種の拡散 火炎で論ずるには無理があると思われますが，いかがで しょうか.

〔回答〕（1）ご指摘のとおり, 数密度分布と体積分率 分布の両者の表示が必要でない.しかしながら, 数密度 值及び体皘分率值を, 定量的に絶対值で理解するために は便利である.

（2）すすの分解効果は温度と酸素濃度によって大きく 依存される.図8亿抏いて温度レベルが $800 \mathrm{~K}$ 付近まで はすす粒子の分解 (燃焼) に有効である. 火炎後流のての 温度レベルはすす質量濃度分布のピーク值をかなり過ぎ た分解領域 ( (a) 図では $L_{\mathrm{c}}=400 \mathrm{~mm},(\mathrm{~b})$ 図では $L_{\mathrm{c}}=$ $300 \mathrm{~mm})$ である. ゆえに，(b) 図 $\left(\theta=60^{\circ}\right)$ ではとくに 低濃度となる。しかしながら，それ以降の領域では拡散 の影響あるいは乱流渦崩壊 $($ (1寸寸 1,2 )の影響のため, 低減さ れると思われる.

(付 1) Magnussen, B. F. and Hjertage., B. H., 16 th Symp. (Int.) on Comb., The Combustion Institute, (1977), 719.

(付 2) 西田 - 向原, 日本舶用機関学会第 36 回 (昭 60 年春季)学術講演会講演論文集, $(1985), 18$. 